University of Nebraska - Lincoln

DigitalCommons@University of Nebraska - Lincoln

Role of Berberis spp. as alternate hosts in generating new races of Puccinia graminis and $P$. striiformis

Yue Jin

USDA-ARS, yue.jin@ars.usda.gov

Follow this and additional works at: https://digitalcommons.unl.edu/usdaarsfacpub

Jin, Yue, "Role of Berberis spp. as alternate hosts in generating new races of Puccinia graminis and $P$. striiformis" (2011). Publications from USDA-ARS / UNL Faculty. 1269.

https://digitalcommons.unl.edu/usdaarsfacpub/1269

This Article is brought to you for free and open access by the U.S. Department of Agriculture: Agricultural Research Service, Lincoln, Nebraska at DigitalCommons@University of Nebraska - Lincoln. It has been accepted for inclusion in Publications from USDA-ARS / UNL Faculty by an authorized administrator of DigitalCommons@University of Nebraska - Lincoln. 


\title{
Role of Berberis spp. as alternate hosts in generating new races of Puccinia graminis and $P$. striiformis
}

\author{
Yue Jin
}

This article is a U.S. government work, and is not subject to copyright in the United States.

Received: 4 August 2010/Accepted: 13 December 2010/Published online: 24 December 2010

(C) Springer Science+Business Media B.V. (outside the USA) 2010

\begin{abstract}
The common barberry and several other Berberis spp. serve as the alternate hosts to two important rust pathogens of small grains and grasses, Puccinia graminis and P. striiformis. Barberry eradication has been practiced for centuries as a means to control stem rust. Diverse virulence variations have been observed in populations of $P$. graminis $\mathrm{f}$. $\mathrm{sp}$. tritici that were associated with susceptible barberries in North America. Barberry likely has played a role in generating new races of $P$. striiformis $\mathrm{f}$. sp. tritici in some regions in the world. Several North American stem rust races, namely races 56, 15B and QCC, initially originated from barberry, were subsequently responsible for generating large-scale epidemics. Thus, sexual cycles on Berberis spp. may generate virulence combinations that could have serious consequences to cereal crop production.
\end{abstract}

Keywords Barberry $\cdot$ Life cycle $\cdot$ Stem rust $\cdot$ Stripe rust - Wheat

Y. Jin $(\bowtie)$

USDA-ARS Cereal Disease Laboratory, University of Minnesota, St. Paul, MN 55108, USA

e-mail: yue.jin@ars.usda.gov

\section{Introduction}

The associations of barberry (Berberis spp.) with cereal rusts were known long ago as evidenced by a law in a French town in the mid-1600 s requiring the destruction of barberries near grain fields (Zadoks and Bouwman 1985), even though the specific fungal species remains unknown. Many interpreted the pathogen to be Puccinia graminis (the causal agent of stem or black rust) after de Bary in 1864 proved heteroecism, i.e. established that stem rust on cereals and aecia on common barberry (Berberis vulgaris) were incited by the same fungus, $P$. graminis. This in turn provided the scientific basis for barberry eradication as a means to control stem rust that was practiced by many countries for more than two centuries. Barberry serving as the alternate host of $P$. striiformis (the causal agent of stripe or yellow rust) was discovered only recently (Jin et al. 2010). In light of this finding, it is equally probable that, in some cases stripe rust rather than stem rust, might have been the intended target for control by the destructions of barberries practiced in the 17 th and 18 th centuries.

\section{Barberry as a source of genetic variation for Puccinia graminis f. sp. tritici}

The intended purpose of eradicating common barberry plants in the vicinity of grain fields was to 
eliminate initial inoculum of $P$. graminis f. sp. tritici $(P g t)$ coming from barberries to grain fields (Stakman 1919) at an earlier date than might be expected from incoming wind-borne urediniospores. The role of barberry in generating new virulence combinations was not known until the concept of sex in rust fungi was established (Craigie 1927), and new races of $P g t$ were obtained in hybridization experiments (Waterhouse 1929; Newton et al. 1930; Stakman et al. 1930). A decade earlier, however, Stakman (1919) suspected that hybridization between strains might be occurring on barberry, generating new races. A careful examination of the effects of barberry eradication on stem rust in the United States by Roelfs (1982) revealed two unintended but remarkable benefits: reduction in the number of races and stabilization of the wheat stem rust population. The population of $P g t$ east of the Rocky Mountains in North America, though historically diverse (Roane et al. 1960) became asexual as a result of barberry eradication. The number of races in the population declined steadily, a trend that continues to this day. In the past decade, a single race (QFCSC) has dominated the $P g t$ population east of the Rocky Mountains, a region with approximately 60 million acres (about 24 million hectares) of wheat and barley grown annually. Most of this area is considered to be conducive for stem rust development.

In contrast to the simple race structure in the asexual population east of the Rocky Mountains, diverse races of $P g t$ were found in the Pacific Northwest region of the United States (Roelfs and Groth 1980; Burdon and Roelfs 1985). These races are presumably a part of a sexual population due to the observed diversity and the presence of aerial infections on Berberis spp. in the region. Recent surveys identified an active sexual population in a relatively small area bordering the states of Washington and Idaho where B. vulgaris, Mahonia repens and M. aquifolium are present. Inoculation experiments using aeciospores from these species identified isolates belonging to $P$. graminis $\mathrm{f}$. sp. tritici and P. graminis f. sp. secalis, and isolates that attacked Elymus glaucus and 'Hiproly' barley (Y. Jin, unpublished) but not wheat. Work is in progress to characterize the host specificity of these isolates. In 2007 a barley field in northeastern Washington was severely infected by $P$. graminis. Analyses of 83 single-pustule isolates derived from a single stem rust sample collected from this field identified 23 races, many of which were further differentiated on a set of supplemental lines consisting of mostly susceptible genotypes (Rouse et al. 2009). In 2009 a total of 16 races were identified from stem rust samples collected from a single wheat field in the Palouse region bordering Washington and Idaho (Y. Jin, unpublished). These races were differentiated by virulence/avirulence on six resistance genes: $\operatorname{Sr} 5$ (line ISr5Ra), $\quad \operatorname{Sr} 7 b$ (ISr7bRa), $\quad \operatorname{Sr} 8 a$ (ISr8Ra), $\quad \operatorname{Sr} 9 a$ (ISr9aRa), Sr9d (ISr9dRa), and SrMcN (McNair 701). Races of $P g t$ with broad virulence have also been isolated from barberry plants in Russia in recent years (Lekomtseva et al. 2006).

\section{Implications of barberry for generating races of Puccinia graminis f. sp. tritici that have been consequential in North America}

Race 56 of $P g t$, a race responsible for the severe stem rust epidemics in the mid-1930 s in North America, originated from barberry. The race was first found on barberries in Iowa and Nebraska in 1928 (Stakman and Rodenhiser 1958). Race 56 was virulent to Triumph $(\operatorname{SrTmp}+)$, a winter wheat cultivar developed by a farmer in Oklahoma in the 1920s. Triumph became the predominant genetic background in hard red winter wheat throughout the southern Great Plains because of its early maturity, rust resistance, and high yield. Race 56 also was virulent to Kanred ( $\mathrm{rr} 5$, a common stem rust resistance gene present in winter wheat on the central Plains during this era) and Ceres ( $S r 7 b, S r 28)$, a spring wheat cultivar developed for stem rust resistance that dominated the area in the northern Great Plains. The combination of virulence to these genes enabled race 56 to cause epidemics because it was able to establish and multiply in the southern and central Great Plains, a necessary condition for developing epidemics in the northern Great Plains when barberry was no longer functional as a source of initial inoculum in the region. Epidemiologically, a nearly identical, but more dramatic situation happened two decades later with the epidemics of race 15B. Race 15B was first identified on barberries in Iowa in 1939 and persisted near barberry plants at a low frequency for many years before it caused epidemics in North America in the mid-1950 s (Stakman and Rodenhiser 1958). Although the ability of race $15 B$ to attack Thatcher wheat and durum cultivars carrying $\mathrm{Sr} 9 \mathrm{e}$ 
might have been responsible for inciting epidemics in the northern Great Plains and Prairie Provinces of Canada, it was its ability to attack Triumph wheat that enabled inoculum to build up in the south. Stem rust isolates with virulence to SrTmp in North America were rare except in the race 15B lineage and race 56 that originated on barberries.

Between 1989 and 1993, race QCC caused some localized epidemics on barley crops in the northern Great Plains of United States and Prairie Provinces of Canada. This race was first discovered in 1984 in British Columbia (Martens et al. 1989), a Canadian province adjacent to the state of Washington where sexual populations of $P g t$ were known to be present. It is highly likely that QCC originated on barberry because a race with an identical virulence pattern to QCC (i.e. QCCJB) was recently identified from collections near Berberis spp. in the Pacific Northwest (Y. Jin, unpublished). Although QCC was avirulent to the majority of wheat cultivars grown in the Great Plains, it was virulent on Karl, a popular winter wheat cultivar grown in the southern and central Great Plains. This race is one of only a few identified in the North American stem rust population that is virulent to Rpgl (or T-gene), a gene deployed in nearly every barley cultivar in the northern Great Plains (Steffenson 1992). The combination of sufficient inoculum buildup on susceptible wheat in the south and the ability to attack the barley crop in the north enabled QCC to develop into epidemics. Frequencies of race QCC declined steadily after the removal of the susceptible wheat cultivar in the southern and central Great Plains.

\section{Has barberry played a role in generating races of Puccinia striiformis f. sp. tritici?}

A previous working assumption that $P$. striiformis $\mathrm{f}$. sp. tritici (Pst) is asexual, under which interpretations were made in attempts to explain some of the observed variation for virulence, is no longer correct in light of the recent discovery of the alternate host, Berberis spp. through laboratory inoculation experiments. We hypothesized that in areas where wheat and stripe rust-susceptible Berberis spp. coexist, sexual recombination has likely played an active role in contributing to the variability of Pst (Jin et al. 2010). Variation generated via the sexual cycle obviously can provide a more satisfactory interpretation for the observed virulence and genetic diversity in some of the stripe rust "hot spots" around the world, as in the case of western China (Chen et al. 2009; Duan et al. 2010). Berberis spp. are ubiquitous both in their native habitats and as introduced ornamentals in many parts of the world. Although only a few species of Berberis have been tested against stripe rust, the known susceptible species, B. chinensis, B. holstii, B. vulgaris, and B. koreana, represent several diverse sections in Berberis (Ahrendt 1961; Kim et al. 2004), a genus with nearly 500 described species. Thus, more stripe rust susceptible Berberis spp. are likely to be found.

\section{Conclusions}

A large number of races of $P$. graminis f. sp. tritici were found on or near barberry plants in North America, including those that were consequential in generating large-scale epidemics. It is safe to assume that the unique virulence combinations that equipped these races to overcome different cereal resistance genes in different regions were assembled through the sexual cycle. Berberis spp. likely played an active role in generating new races in P. striiformis f. sp. tritici, although evidence for this is circumstantial at this time. Old and recently emerging evidence continues to be gathered about barberries because they harbor two of the most damaging cereal rusts, $P$. graminis $\mathrm{f}$. $\mathrm{sp}$. tritici and $P$. striiformis f. sp. tritici. Virulence combinations generated through the sexual cycle on Berberis spp., however rare, can have serious and long lasting impacts on cereal crops.

\section{References}

Ahrendt L (1961) Berberis and Mahonia, a taxonomic revision. Bot J Linn Soc 57:1-410

Burdon JJ, Roelfs AP (1985) Isozyme and virulence variation in asexually reproducing populations of Puccinia graminis and $P$. recondita on wheat. Phytopathology 75:907-913

Chen WQ, Wu LR, Liu TG, Xu SC, Jin SL, Peng YL, Wang BT (2009) Race dynamics, diversity, and virulence evolution in Puccinia striiformis f. sp. tritici, the causal agent of wheat stripe rust in China from 2003 to 2007. Plant Dis 93:1093-1101

Craigie JH (1927) Discovery of the function of the pycnia of the rust fungi. Nature 120:765-767

Duan X, Tellier A, Wan A, Leconte M, de Vallavieille-Pope C, Enjalbert J (2010) Puccinia striiformis f. sp. tritici 
presents high diversity and recombination in the oversummering zone of Gansu, China. Mycologia 102:44-53

Jin Y, Szabo L, Carson M (2010) Century-old mystery of Puccinia striiformis life history solved with the identification of Berberis spp. as an alternate host. Phytopathology 100:432-435

Kim YD, Kim SH, Landrum LR (2004) Taxonomic and phytogeographic implications from ITS phylogeny in Berberis (Berberidaceae). J Plant Res 117:175-182

Lekomtseva SN, Volkova VT, Zaitseva LG, Chaika MN (2006) Races of Puccinia graminis f. sp. tritici in the Russian federation in 2004. Ann Wheat Newsl 52:100-101

Martens JW, Dunsmore KM, Harder DE (1989) Incidence and virulence of Puccinia graminis in Canada on wheat and barley in 1988. Can J Plant Pathol 11:424-430

Newton M, Johnson T, Brown AM (1930) A preliminary study on the hybridization of physiologic forms of Puccinia graminis tritici. Sci Agric 10:721-731

Roane CW, Stakman EC, Leogering WQ, Stewart DM, Watson WM (1960) Survival of physiologic races of Puccinia graminis var. tritici on wheat near barberry bushes. Phytopathology 50:40-44

Roelfs AP (1982) Effects of barberry eradication on stem rust in the United States. Plant Dis 66:177-181
Roelfs AP, Groth JV (1980) A comparison of virulence phenotypes in wheat stem rust populations reproducing sexually and asexually. Phytopathology 70:855-862

Rouse MN, Stoxen S, Chen X, Szabo LJ, Jin Y (2009) Diverse stem rust races found in a single field in Washington, USA. Phytopathology 99:S111 (abstract)

Stakman EC (1919) The black stem rust and the barberry. In: US Department of Agriculture Year book, pp 75-100

Stakman EC, Rodenhiser HA (1958) Race 15B of wheat stem rust-what it is and what it means. Adv Agron 10:143-165

Stakman EC, Levin MN, Cotter RU (1930) Origin of physiologic forms of Puccinia graminis through hybridization and mutation. Sci Agric 10:707-720

Steffenson BJ (1992) Analysis of durable resistance to stem rust in barley. Euphytica 63:153-167

Waterhouse WL (1929) A preliminary account of the origin of two new Australian physiologic forms of Puccinia graminis tritici. Proc Linn Soc NSW 54:96-106

Zadoks JC, Bouwman JJ (1985) Epidemiology in Europe. In: Roelfs AP, Bushnell WR (eds) The cereal rusts: diseases, distribution, epidemiology, and control, vol 2. Academic Press, Orlando, pp 329-369 